\title{
The Development of a Training Model for Occupational Competency of Production Supervisor
}

\author{
Chaloemphon Meechai and Somyot Jedjaroenruk
}

\begin{abstract}
The Occupational competency development of personnels in any organization was considered to be a vital factor for economic development especially in business and industry sectors. Supervisor played an important role in industrial development, therefore, the training of personnels to improve their occupational competency is very essential. These research main objectives aimed to investigate the components of work competency of the production supervisor in textile industry as well as to develop the training course for these personnels. The training course was then used to train target group to assess their training achievement. The assessment of their competencies obtained for the training was conducted by evaluating the productivity of work done by workers. The population of the study was production supervisors of textile industry situated in Ubonratchathani, THAILAND. The samples of 30 supervisors were selected from Vertex Apparel Co., Ltd which is a textile and garment company.

The results of this study were as follows: 1) In order to develop work competency components, a total of two hundred production supervisors in textile and garment industry were selected as research samples. Accordingly, work competency components of these personnels comprised of six aspects, i.e. leadership, planning, monitoring and evaluation, process improvement, problem solving, communication skill. 2) The sample group was then trained for three months using to develop 5 Modules for training course. Data were collected at the end of training to assess their learning achievement by means of percentage. The productivity of work done was collected every 15 days for six months to compare with productivity obtained before the training. 3) The finding on learning achievement is $81.5 \%$ which corresponded to the hypothesis. The result was an increase in productivity of about $10 \%$, a $60 \%$ reduction in defects. The finding also corresponded to the hypothesis.
\end{abstract}

Index Terms-Development, occupational competency, training model, production supervisor.

\section{INTRODUCTION}

The economy of Thailand is a newly industrialized economy. It is a heavily export-dependent economy, with exports accounting for more than two thirds of gross domestic product (GDP). The economic Growth of Thailand expanding has been very rapidly. As in Fig. 1 the Gross Domestic Product (GDP) in Thailand expanded 1.1 percent in the third quarter of 2014 over the previous quarter. Competencies have been used for all types of organizations,

Manuscript received January 21, 2015; revised March 13, 2015.

The authors are with the Department of Technological Education, Faculty of Technical Education, King Mongkut's University of Technology North Bangkok, Thailand (e-mail: chaloemphon.m@umt.ac.th, somyot@kht.co.th). including private clubs [1]. Competencies were originally used in business and education sectors as a means to select employees or students [2]. One of the framework which could be utilized in management development is management competencies. Competency is strategically important element of an organization as it provides competitive advantages and inhibits the performance. Fast developments in technology, changes in customer expectations and globalization require the production to be active, more flexible [3].

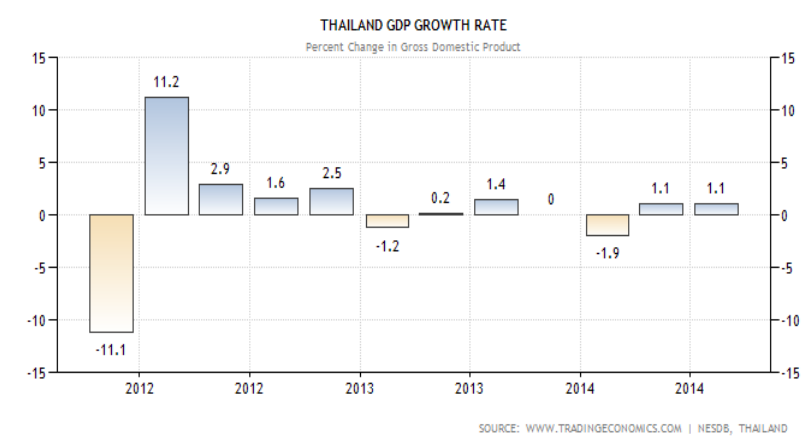

Fig. 1. Thailand GDP growth rate

\section{Statement of THE PRoblem}

The management problem of this research was the improvement process for the development of production supervisors. A production supervisor is the Middle level of organization's management hierarchy and they are responsible for managing the work of the employees. It is essential that the characteristics of the supervisory job, defined by its competencies, be known. This is important in order to properly and adequately establish organizational supervisory positions, select personnel for those positions, and train personnel in those supervisory positions. It is also important from a human resources perspective to use the supervisors' competencies in developing job descriptions and performance reviews, because of anti-discrimination statutes and court decisions, and because it is good management practice. The need to research the competencies of a production supervisor has many marketplace origins as well as to develop the training course for these personnel.

\section{PURPOSES OF THE STUdY}

The research main purposes were to investigate the components of work competency of the production supervisor in textile industry as well as to develop the training course for these personnels. The training courses were then used to train target group to assess their training 
achievement. The assessment of their competencies obtained for the training is conducted by evaluating the productivity of work done by their workers. As in Fig. 2 the conceptual framework.

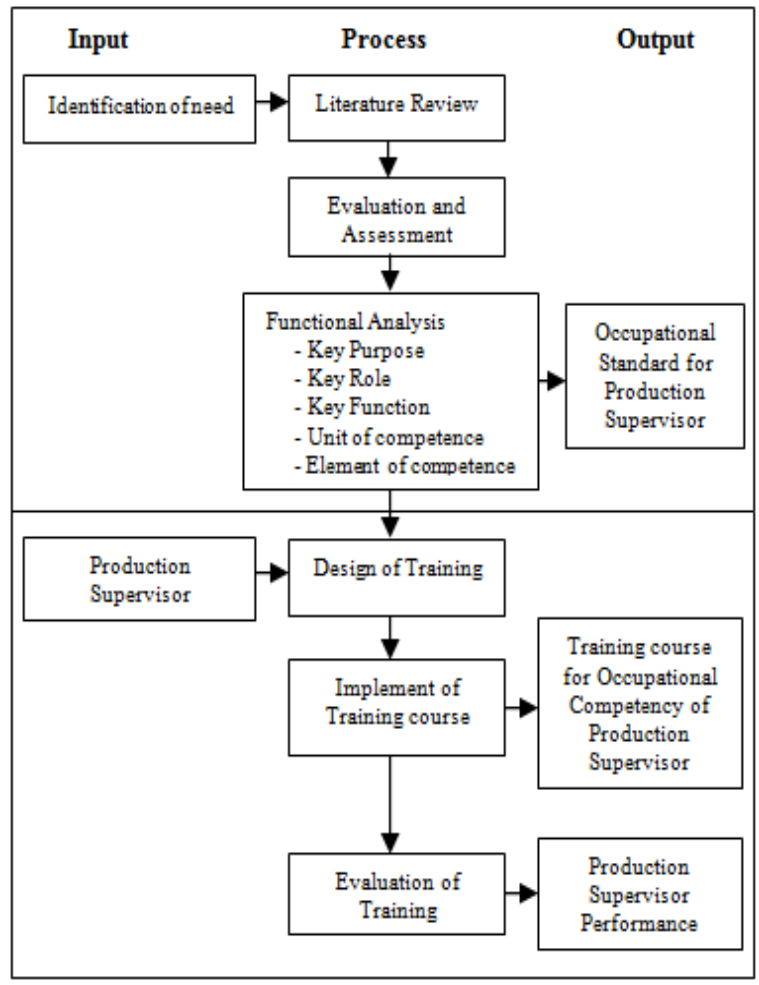

Fig. 2. The conceptual framework.

\section{SCOPE OF STUDY}

The population of the study are production supervisors of textile industry situated in Ubonratchathani, Thailand. The samples of 30 supervisors were selected from Vertex Apparel Co., Ltd which is a textile and garment company.

\section{Methodology}

\section{A. The First Phase}

The development of occupational standard for production supervisor.

1) Analyze and synthesize former researches relevant to identification of need.

2) Literature review about occupational competency.

3) Design the evaluation and assessment form for functional analysis

4) Present the assessment to the advisors for consideration and revision.

5) The assessment were verified for content validity by a panel of 5 experts for focus group discussion and using content validity ratio (CVR) and validated for reliability using alpha coefficients. Six subjects of each sample group were used for try-out for each assessment. The Statistical Package for the Social Science for Window (SPSS/FW) was used for computing the reliability coefficient of the questionnaires. Chronbach's Alpha $(\alpha)$ was .93. Internal consistency reliabilities were established based on this study. Subscale ranges were .932 for leadership, .932 for planning, .934 for monitoring and evaluation, .928 for process improvement, .895 for problem solving and .905 for communication skill.

\section{B. The Second Phase}

This phase was to design the training model.

1) Present the designed model to the 5 experts in the field of instructional design for review and evaluate the suitability.

2) The model was modified according to the experts' suggestions.

3) After modification, presenting the model in the form of diagram with report. As in Fig. 3 the training model

4) Analyze the results of evaluation of the model by mean $(\bar{x})$ and standard deviation (S.D.) consisting of 6 criteria for evaluation according to the idea of Likert scale.

\section{The Third Phase}

This phase was to implementing the training course. The training course is then used to train target group to assess their training achievement.

\section{The Fourth Phase}

This phase was to evaluate the training course. Evaluating a program for its effectiveness determines how well the learners mastered the learning outcomes of the training course. The most important measure of program effectiveness is how well the knowledge, attitude, and skill delivered in the program were transferred into jobs and employment opportunities. Data were collected at the end of training to assess their learning achievement by means of percentage. The Productivity of work done was collected every 15 days for six months to compare with productivity obtained before the training.

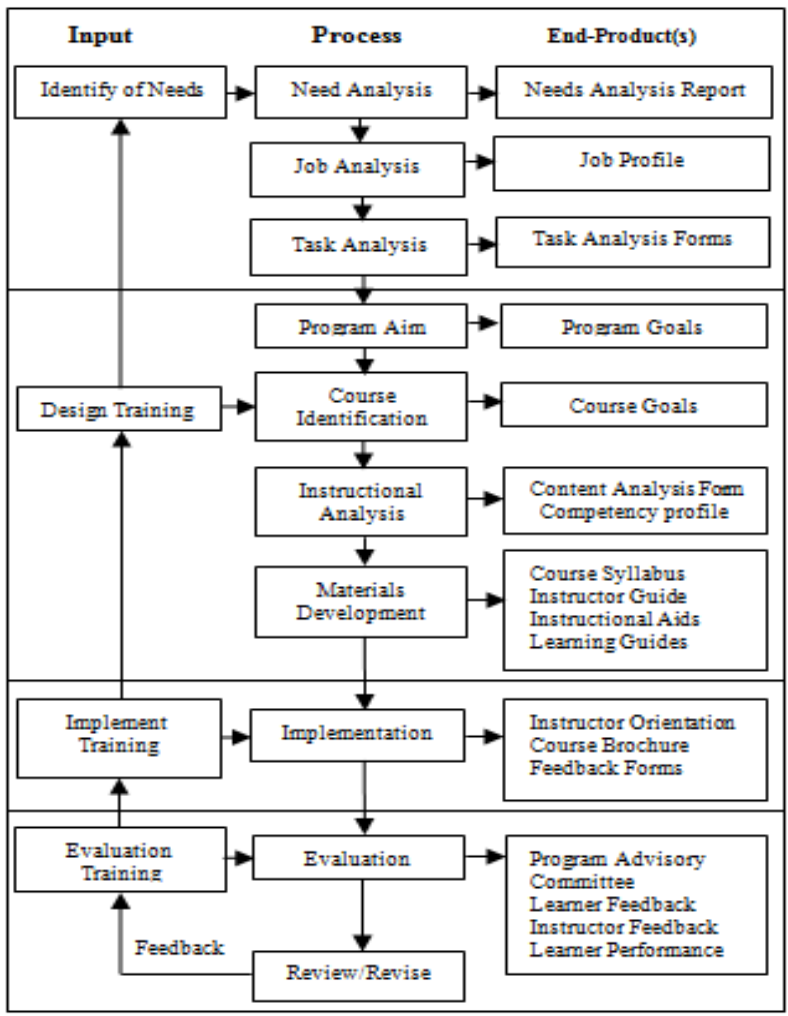

Fig. 3. The training model. 


\section{RESUlTS}

The study identified six most important elements of competence in the value stream supervisor (VSS). Evaluation the result of achievements can be summarized below.

The results of evaluation of functional analysis by mean $(x)$ and standard deviation (S.D.) consisting of 49 criteria for evaluation.

\section{TABLE I: RESULTS OF COMPONENTS OF WORK COMPETENCY}

\begin{tabular}{|c|c|c|c|c|}
\hline No. & $\begin{array}{l}\text { Components of work } \\
\text { competency }\end{array}$ & $\begin{array}{l}\text { Mean } \\
(\bar{x})\end{array}$ & $\begin{array}{c}\text { standard } \\
\text { deviation } \\
\text { (S.D.) }\end{array}$ & Result \\
\hline & Leadership & & & \\
\hline 1 & Assign equipment to jobs & 4.86 & 0.70 & High level \\
\hline 2 & Assigning workers to jobs & 4.65 & 0.65 & High level \\
\hline 3 & $\begin{array}{l}\text { Authorizing non-routine } \\
\text { actions by workers }\end{array}$ & 4.73 & 0.72 & $\begin{array}{l}\text { Very high } \\
\text { level }\end{array}$ \\
\hline 4 & Conduct team briefings & 4.61 & 0.68 & High level \\
\hline 5 & $\begin{array}{l}\text { Coordinating work of a } \\
\text { team }\end{array}$ & 4.73 & 0.66 & $\begin{array}{c}\text { Very high } \\
\text { level }\end{array}$ \\
\hline 6 & Manage multiple teams & 4.29 & 0.65 & High level \\
\hline 7 & $\begin{array}{l}\text { Motivate workers to } \\
\text { change or improve their } \\
\text { performance }\end{array}$ & 4.19 & 0.64 & High level \\
\hline 8 & $\begin{array}{l}\text { Manage work schedule } \\
\text { Planning }\end{array}$ & 4.43 & 0.67 & High level \\
\hline 9 & $\begin{array}{l}\text { Attending planning } \\
\text { meetings }\end{array}$ & 4.41 & 0.68 & High level \\
\hline 10 & $\begin{array}{l}\text { Dealing with immediate } \\
\text { customer/client concerns }\end{array}$ & 4.23 & 0.67 & High level \\
\hline 11 & Manage work schedule & 4.41 & 0.67 & High level \\
\hline 12 & Managing a budget & 4.30 & 0.65 & High level \\
\hline 13 & $\begin{array}{l}\text { Plan a budget } \\
\text { Monitoring\& } \\
\text { Evaluation }\end{array}$ & 4.35 & 0.67 & High level \\
\hline 14 & Give verbal warnings & 4.47 & 0.72 & High level \\
\hline 15 & Give written warnings & 4.30 & 0.74 & High level \\
\hline 16 & $\begin{array}{l}\text { Giving informal feedback } \\
\text { on performance }\end{array}$ & 4.35 & 0.70 & High level \\
\hline 17 & $\begin{array}{l}\text { Hold formal performance } \\
\text { reviews }\end{array}$ & 4.26 & 0.69 & High level \\
\hline 18 & Maintain personnel records & 4.28 & 0.60 & High level \\
\hline 19 & $\begin{array}{l}\text { Provide praise when } \\
\text { deserved }\end{array}$ & 4.27 & 0.60 & High level \\
\hline 20 & Recommending promotions & 4.25 & 0.62 & High level \\
\hline 21 & $\begin{array}{l}\text { Scheduling workers to shifts } \\
\text { and overtime }\end{array}$ & 4.43 & 0.63 & High level \\
\hline 22 & $\begin{array}{l}\text { Spot check production } \\
\text { amounts }\end{array}$ & 4.32 & 0.66 & High level \\
\hline 23 & $\begin{array}{l}\text { Spot check production } \\
\text { quality }\end{array}$ & 4.82 & 0.73 & $\begin{array}{l}\text { Very high } \\
\text { level }\end{array}$ \\
\hline 24 & Do hourly pay roll & 4.62 & 0.61 & High level \\
\hline 25 & $\begin{array}{l}\text { Keeping track of vacation } \\
\text { and personal time } \\
\text { Process Improvement }\end{array}$ & 4.75 & 0.64 & High level \\
\hline 26 & Assist in worker training & 4.38 & 0.69 & High level \\
\hline 27 & Assist workers with tasks & 4.54 & 0.82 & High level \\
\hline 28 & Attending review meetings & 4.43 & 0.72 & High level \\
\hline 29 & Controlling operations costs & 4.56 & 0.76 & High level \\
\hline 30 & $\begin{array}{l}\text { Enforce cleanliness } \\
\text { standards }\end{array}$ & 4.22 & 0.62 & High level \\
\hline 31 & $\begin{array}{l}\text { Enforce work rules and } \\
\text { policies }\end{array}$ & 4.56 & 0.64 & High level \\
\hline 32 & $\begin{array}{l}\text { Implement efficiency } \\
\text { improvements }\end{array}$ & 4.35 & 0.63 & High level \\
\hline 33 & $\begin{array}{l}\text { Maintain computer files and } \\
\text { information }\end{array}$ & 4.78 & 0.71 & $\begin{array}{l}\text { Very high } \\
\text { level }\end{array}$ \\
\hline
\end{tabular}

\begin{tabular}{|c|c|c|c|c|}
\hline No. & $\begin{array}{l}\text { Components of work } \\
\text { competency }\end{array}$ & Mean $(\bar{x})$ & $\begin{array}{c}\text { standard } \\
\text { deviation } \\
\text { (S.D.) }\end{array}$ & Result \\
\hline 34 & $\begin{array}{l}\text { Provide cover for staff to } \\
\text { take breaks }\end{array}$ & 4.34 & 0.65 & High level \\
\hline 35 & $\begin{array}{l}\text { Provide on the job technical } \\
\text { training }\end{array}$ & 4.44 & 0.67 & High level \\
\hline 36 & $\begin{array}{l}\text { Provide workers technical } \\
\text { advice }\end{array}$ & 4.53 & 0.73 & High level \\
\hline \multirow[t]{2}{*}{37} & $\begin{array}{l}\text { Attend safety meetings, } \\
\text { audits, and training of } \\
\text { people }\end{array}$ & 4.82 & 0.72 & $\begin{array}{c}\text { Very high } \\
\text { level }\end{array}$ \\
\hline & Problem Solving & & & \\
\hline 38 & $\begin{array}{l}\text { Handle immediate materials } \\
\text { issues }\end{array}$ & 4.51 & 0.60 & High level \\
\hline 39 & $\begin{array}{l}\text { Help implement changes in } \\
\text { work practices }\end{array}$ & 4.42 & 0.63 & High level \\
\hline 40 & $\begin{array}{l}\text { Resolve conflicts among } \\
\text { workers }\end{array}$ & 4.21 & 0.64 & High level \\
\hline 41 & $\begin{array}{l}\text { Resolve immediate } \\
\text { equipment problems }\end{array}$ & 4.45 & 0.72 & High level \\
\hline 42 & $\begin{array}{l}\text { Resolve immediate } \\
\text { problems with production } \\
\text { space }\end{array}$ & 4.72 & 0.71 & $\begin{array}{c}\text { Very high } \\
\text { level }\end{array}$ \\
\hline 43 & $\begin{array}{l}\text { Resolve immediate staffing } \\
\text { problems }\end{array}$ & 4.61 & 0.73 & High level \\
\hline \multirow[t]{2}{*}{44} & $\begin{array}{l}\text { Resolve immediate work } \\
\text { flow or process problems }\end{array}$ & 4.33 & 0.68 & High level \\
\hline & Communication skill & & & \\
\hline 45 & Keep management informed & 4.49 & 0.75 & High level \\
\hline 46 & $\begin{array}{l}\text { Keep workers and } \\
\text { management informed }\end{array}$ & 4.52 & 0.64 & High level \\
\hline 47 & $\begin{array}{l}\text { Keep workers informed of } \\
\text { goals and mission }\end{array}$ & 4.30 & 0.61 & High level \\
\hline 48 & Meet with other supervisors & 4.29 & 0.63 & High level \\
\hline \multirow[t]{2}{*}{49} & Perform work tasks & 4.43 & 0.65 & High level \\
\hline & SUM & 4.46 & 0.67 & High level \\
\hline
\end{tabular}

The results of evaluation of the model by mean $(\bar{x})$ and standard deviation (S.D.) consisting of 5 criteria for evaluation

TABLE II: RESULTS OF EVALUATION OF THE MODEL

\begin{tabular}{|c|c|c|c|c|}
\hline No. & Training model & Mean $(\bar{x})$ & $\begin{array}{c}\text { standard } \\
\text { deviation } \\
\text { (S.D.) }\end{array}$ & Result \\
\hline 1 & Identify of Needs & 4.80 & 0.57 & High level \\
\hline 2 & Design Training & 4.86 & 0.70 & $\begin{array}{c}\text { Very high } \\
\text { level }\end{array}$ \\
\hline 3 & $\begin{array}{l}\text { Implement } \\
\text { Training }\end{array}$ & 4.65 & 0.65 & High level \\
\hline 4 & $\begin{array}{l}\text { Evaluation } \\
\text { Training }\end{array}$ & 4.73 & 0.72 & $\begin{array}{c}\text { Very high } \\
\text { level }\end{array}$ \\
\hline \multirow[t]{2}{*}{5} & Review/Revise & 4.61 & 0.68 & High level \\
\hline & SUM & 4.73 & 0.66 & High level \\
\hline
\end{tabular}

After training, the production supervisors who were trained, their learning achievement improved to $81.5 \%$.

TABLE III: THE LEARNING ACHIEVEMENT

\begin{tabular}{llcc}
\multicolumn{4}{c}{ TABLE III: THE LEARNING ACHIEVEMENT } \\
\hline \hline No. & Position & $\begin{array}{c}\text { Pre-test } \\
\text { (40 points) }\end{array}$ & $\begin{array}{c}\text { Post-test } \\
\text { (40 points) }\end{array}$ \\
\hline 1 & Senior Director & 27 & 32 \\
2 & Director of Production & 27 & 33 \\
3 & Asst. Director & 28 & 33 \\
\hline
\end{tabular}


TABLE III: THE LEARNING ACHIEVEMENT (CONT.)

\begin{tabular}{|c|c|c|c|}
\hline No. & Position & $\begin{array}{c}\text { Pre-test } \\
\text { (40 points) }\end{array}$ & $\begin{array}{c}\text { Post-test } \\
\text { (40 points) }\end{array}$ \\
\hline 4 & Manager 2 & 29 & 31 \\
\hline 5 & Manager 3 & 28 & 33 \\
\hline 6 & Manager 4 & 27 & 33 \\
\hline 7 & CI Manager & 28 & 34 \\
\hline 8 & Asst. HR Manager & 29 & 33 \\
\hline 9 & Asst. Security Manager & 28 & 32 \\
\hline 10 & Asst. QA Manager & 29 & 32 \\
\hline 11 & Accounting Manager & 27 & 33 \\
\hline 12 & Asst. Accounting Manager & 27 & 32 \\
\hline 13 & IE Supervisor & 28 & 33 \\
\hline 14 & Knit Supervisor & 27 & 34 \\
\hline 15 & Store Supervisor & 26 & 33 \\
\hline 16 & Packing Supervisor & 28 & 33 \\
\hline 17 & Improvement Supervisor & 27 & 32 \\
\hline 18 & QC Supervisor & 29 & 32 \\
\hline 19 & ACC Store Supervisor & 26 & 32 \\
\hline 20 & Heat Supervisor & 27 & 32 \\
\hline 21 & QA Supervisor & 29 & 33 \\
\hline 22 & QA & 27 & 33 \\
\hline 23 & QA & 29 & 33 \\
\hline 24 & Planning & 28 & 33 \\
\hline 25 & HRD & 28 & 33 \\
\hline 26 & VSS & 27 & 33 \\
\hline 27 & VSS & 26 & 32 \\
\hline 28 & VSS & 27 & 31 \\
\hline 29 & VSS & 27 & 31 \\
\hline \multirow[t]{4}{*}{30} & VSS & 27 & 32 \\
\hline & $\sum X$ & 855 & 978 \\
\hline & $\bar{X}$ & 28.50 & 32.60 \\
\hline & $\bar{X} \%$ & 71.25 & 81.50 \\
\hline
\end{tabular}

From Table III, shown that the learning achievement improved to $81.50 \%$ was appropriateness in highest level.

Evaluation of productivity was an increase in productivity of about $10 \%$, a $60 \%$ reduction in defects.

From Table IV, shown that the score of management test for supervisor $83.32 \%$ and $88.83 \%$ was appropriateness in highest level.

\section{TABLE V: THE EVALUATION OF PRODUCTIVITY}

\begin{tabular}{|c|c|c|c|}
\hline No. & Period of time & $\begin{array}{c}\text { VSS } 1 \\
\text { (300 units) }\end{array}$ & $\begin{array}{c}\text { VSS } 2 \\
\text { (300 units) }\end{array}$ \\
\hline 1 & VSS-15 & 230 & 270 \\
\hline 2 & VSS-16 & 240 & 265 \\
\hline 3 & VSS-17 & 235 & 250 \\
\hline 4 & VSS-18 & 230 & 270 \\
\hline 5 & VSS-19 & 245 & 280 \\
\hline 6 & VSS-20 & 235 & 235 \\
\hline 7 & VSS-21 & 230 & 265 \\
\hline 8 & VSS-25 & 230 & 280 \\
\hline 9 & VSS-26 & 245 & 265 \\
\hline 10 & VSS-27 & 240 & 270 \\
\hline 11 & VSS-28 & 240 & 280 \\
\hline 12 & VSS-29 & 225 & 265 \\
\hline 13 & VSS-30 & 230 & 275 \\
\hline \multirow[t]{4}{*}{14} & VSS-31 & 235 & 275 \\
\hline & $\Sigma X$ & 3,290 & 3,745 \\
\hline & $\bar{X}$ & 235 & 267.50 \\
\hline & $X \%$ & 78.33 & 89.16 \\
\hline
\end{tabular}

From Table V, shown that the evaluation of productivity was an increase in productivity of about 10\%. As in Fig. 4, the Value Stream productivity.

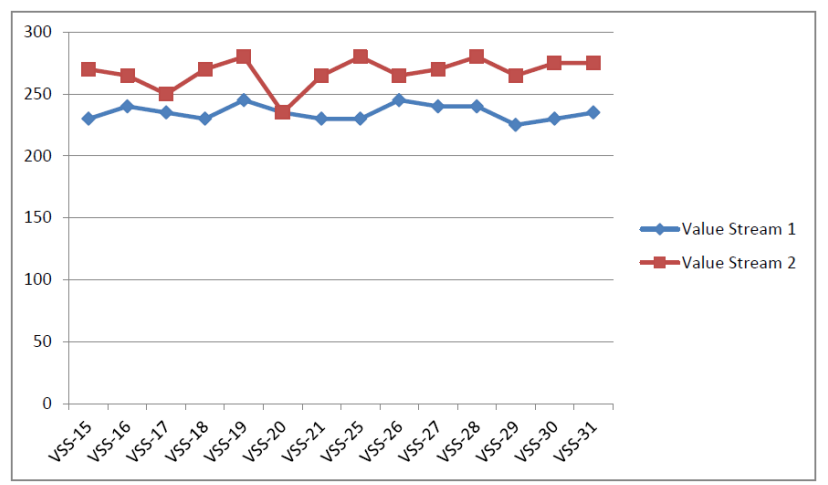

Fig. 4. The value stream productivity.

TABLE VI: THE REDUCTION IN DEFECTS

\begin{tabular}{|c|c|c|c|}
\hline No. & Period of time & $\begin{array}{c}\text { VSS } 1 \\
\text { (pieces) }\end{array}$ & $\begin{array}{l}\text { VSS } 2 \\
\text { (pieces) }\end{array}$ \\
\hline 1 & VSS-15 & 8 & 2 \\
\hline 2 & VSS-16 & 9 & 2 \\
\hline 3 & VSS-17 & 8 & 3 \\
\hline 4 & VSS-18 & 7 & 2 \\
\hline 5 & VSS-19 & 9 & 2 \\
\hline 6 & VSS-20 & 8 & 2 \\
\hline 7 & VSS-21 & 9 & 2 \\
\hline 8 & VSS-25 & 8 & 1 \\
\hline 9 & VSS-26 & 8 & 1 \\
\hline 10 & VSS-27 & 8 & 1 \\
\hline 11 & VSS-28 & 7 & 2 \\
\hline 12 & VSS-29 & 7 & 2 \\
\hline 13 & VSS-30 & 8 & 2 \\
\hline \multirow[t]{4}{*}{14} & VSS-31 & 7 & 2 \\
\hline & $\Sigma X$ & 111 & 26 \\
\hline & $\underline{\bar{X}}$ & 7.92 & 1.85 \\
\hline & $\bar{X} \%$ & 79.2 & 18.5 \\
\hline
\end{tabular}

From Table VI, shown that the evaluation of productivity was $60 \%$ reduction in defects.

As in Fig. 5, the reduction in defects.

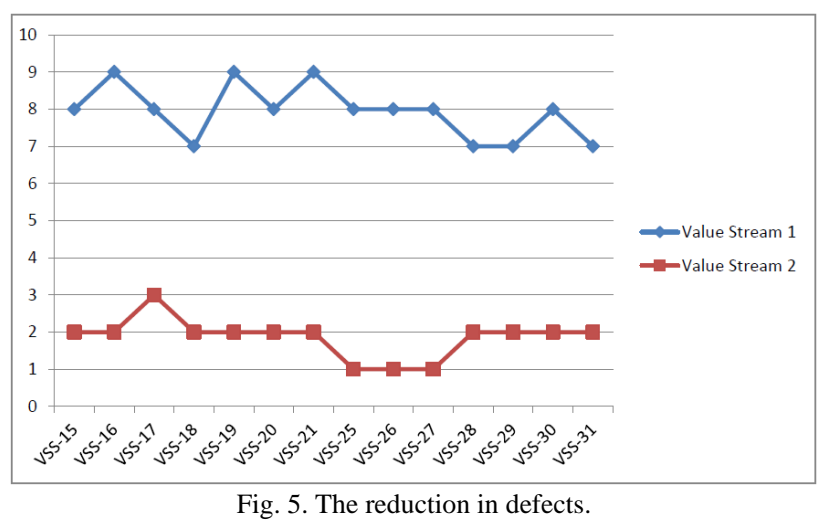

VII. CONCLUSIONS

The following conclusions based on the finding of this study. In order to develop work competency components, a 
total of two hundred production supervisors in textile and garment industry were selected as research samples. Accordingly, work competency components of these personnel comprised six aspects, i.e. leadership, planning, monitoring and evaluation, process improvement, attitude, and communication skill. Therefore, administrators and instructors could develop and encourage the moral, group activity, and public activity.

\section{DISCUSSION}

The literature has established that preparation of today's production supervisors for success in tomorrow's world requires production supervisors to adjust from a traditional performance to the new innovations. Production supervisors are able to perform in leadership, planning, monitoring and evaluation, process improvement, attitude, and communication skill.

\section{RECOMMENDATIONS}

As results of this study, the following recommendations have been formulated:

1) Additional quantitative and qualitative investigations occupational competency of production supervisor should be conducted to examine such factors as machinery improvement.

2) Ongoing development training programs for production supervisors performance should be related with leadership, planning, monitoring and evaluation, process improvement, attitude and communication skill all programs in English.

\section{ACKNOWLEDGMENT}

This study was sponsored by King Mongkut's University of Technology North Bangkok (KMUTNB), Thailand. It was conducted with full cooperation of the Vertex Apparel Co,.Ltd, Thailand. The production supervisors assisted in data collection. The most appreciation goes to the experts. And also, deep appreciation could not be neglected to The Eastern University of Management and Technology who dedicated money, time, and will-power to this research.

\section{REFERENCES}

[1] D. Dubois and J. Rothwel, Competency-Based Human Resource Management, California: Davies-Black Publishing, 2004. ch. 2.

[2] D. Hellriegel, E. Susan, and W. John, A Competency-Based, 2001, pp. 90-104.

[3] D. C. McClelland, Testing for Competence Rather Than for Intelligence, New Jersey: American Psychologist, 1973.

[4] S. Genesh, Competency Base HRM: A Strategic Resource for Competency Mapping, Assessment and Development center, New Delhi Tata : McGraw-Hill Publishing Company Limited, 2004, pp. 47-56.

[5] M. L. Spencer and M. S. Spencer, Competency at Work: Model for Superior Performance, New York: John Wiley \& Sons, 1993.

[6] E. Rick, "Effective use of the web for education design in principles and pedagogy," 1997.

[7] F. Lindsey, "A best-practices guide to developing, implementing, and evaluating an employee training and development program," Dissertation Abstract International, 2004.

[8] L. Pederson, "Tasks and responsibility of a fast-line supervisor in a job shop manufacturing environment in north west Wisconsin," Dissertation Abstract International, 2010.

[9] N. Ladany, M. L. Friedlander, and M. L. Nelson, Critical Events in Psychotherapy Supervision: An Interpersonal Approach, Washington, DC: APA Books, 2005.

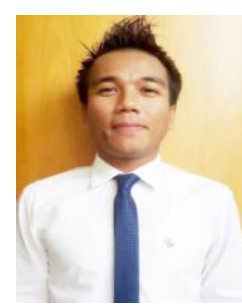

Chaloemphon Meechai is a Ph.D. candidate in technical education technology, Department of Technological Education, Faculty of Technical Education, King Mongkut's University of Technology North Bangkok (KMUTNB), Thailand and he is a lecturer at Department of Industrial Management, the Eastern University of Management and Technology, Thailand. He has experience in industrial management research. He received Rangsit

Universit Research Award 2002.

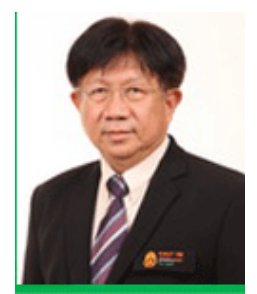

Somyot Jedjaroenruk is a director of Phradabos School, Thailand. He has experience in many positions such as a lecturer at Department of Teacher Training in mechanical engineering, Faculty of Technical Education, King Mongkut's University of Technology North Bangkok (KMUTNB), Thailand. 